\title{
Corporate Power over Human Rights: An Analytical Framework
}

\author{
David BIRCHALLII
}

\begin{abstract}
This paper presents an original framework designed to systematize understanding of corporate power over human rights. The framework disaggregates four sites of this power: corporations have direct power over individuals' human rights, power over the materialities of human rights, power over institutions governing human rights, and power over knowledge around human rights. This disaggregation is derived primarily from the work of Barnett and Duvall and focuses on the effects of corporate activity rather than the Weberian understanding of power as the ability to achieve desired outcomes. The framework captures a broad set of corporate acts based on their (potential) harm to human rights. It is argued that understanding business and human rights through the lens of power can help to advance a more comprehensive account of business impacts on human rights.
\end{abstract}

Keywords: Corporate power, Global justice, International human rights law, Neoliberalism, Political economy

\section{INTRODUCTION}

The extent of business responsibility towards human rights is a major topic within contemporary human rights discourse. ${ }^{1}$ Separately, many scholars have attempted to understand power in the global economy, ${ }^{2}$ and specifically corporate power over actors or

II Conflicts of interest: The author declares none.

* Assistant Professor at University of Nottingham - Ningbo China, Business School Ningbo, Zhejiang, China.

1 David Jason Karp, Responsibility for Human Rights: Transnational Corporations in Imperfect States (Cambridge: Cambridge University Press, 2014); Nadia Bernaz, Business and Human Rights: History, Law and Policy - Bridging the Accountability Gap (London: Routledge, 2016); Dorothée Baumann-Pauly and Justine Nolan, Business and Human Rights: From Principles to Practice (New York: Routledge, 2016).

2 Susan Strange, States and Markets (London: Pinter, 1988); Steven Lukes, Power: A Radical View, $2^{\text {nd }}$ edn. (London: Palgrave Macmillan, 2004); Peter Morriss, Power: A Philosophical Analysis (Manchester: Manchester University Press, 2002). 
arenas such as states, ${ }^{3}$ markets ${ }^{4}$ or global governance. ${ }^{5}$ However, there has been little work done to understand, map and systematize the relationship between corporate power and human rights. ${ }^{6}$ This is a valuable project for at least three reasons. First, as business and human rights (BHR) is evolving and corporations are increasingly accepting a responsibility to respect human rights, ${ }^{7}$ an analysis of corporate power over human rights helps us to understand the breadth of business impacts upon human rights. ${ }^{8}$ Second, it should assist in developing forms of regulation and conceptions of responsibility that respond better to actual corporate practices, rather than relying on extant legal norms and social priorities. Third, as an analytical framework, the power analysis herein can be applied to discrete situations and to discrete rights, allowing more nuanced approaches to BHR in an expansive range of situations.

Power is defined following Barnett and Duvall as 'the production, in and through social relations, of effects that shape the capacities of actors to determine their circumstances and fate.' ${ }^{9}$ From this, corporate power over human rights is defined herein as the production, by business enterprises, in and through social relations, of effects that shape the capacities of individuals to enjoy their human rights. More simply, corporate power over human rights is the ability of business enterprises to shape individuals' human rights realization, retrogression or possibilities. Barnett and Duvall highlight the importance of 'effects on the capacities and courses of action available to actors [that] are unintentionally produced through social relations.' ${ }^{10}$ This leads to a shift away from a Weberian focus on power as the ability to achieve one's goals, ${ }^{11}$ and to a more comprehensive focus on causing influential effects. This approach to understanding power is relevant to human rights because human rights harm is often an externality of business practice. ${ }^{12}$

\footnotetext{
3 Claire A Cutler, Private Power and Global Authority: Transnational Merchant Law in the Global Political Economy (Cambridge: Cambridge University Press, 2003).

4 Claire A Cutler, 'Location “Authority" in the Global Political Economy' (1999) 43:1 International Studies Quarterly, 59; Christopher May, The Global Political Economy of Intellectual Property Rights: The New Enclosures (London: Routledge, 2015).

5 Doris A Fuchs, Business Power in Global Governance (Boulder, CO: Lynne Rienner, 2007); Thomas G Weiss and Rorden Wilkinson, 'Rethinking Global Governance? Complexity, Authority, Power, Change' (2014) 58:1 International Studies Quarterly 207.

6 Florian Wettstein, Multinational Corporations and Global Justice: Human Rights Obligations of a QuasiGovernmental Institution (Stanford: Stanford University Press, 2009); John Gerard Ruggie, 'Multinationals as Global Institution: Power, Authority and Relative Autonomy' (2018) 12:3 Regulation \& Governance 317.

7 UN Office of the High Commissioner of Human Rights (OHCHR), 'Guiding Principles on Business and Human Rights', HR/PUB/11/04 (2011), Principle 13.

8 Following the UNGPs, which discuss a 'corporate responsibility to respect human rights' that applies to 'business enterprises', I use 'corporations' and 'business' interchangeably. The framework applies equally to actors that behave in some ways as businesses, for example as employers, because it is predicated on understanding power and impacts rather than designating responsibility. UN Office of the High Commissioner of Human Rights, 'Interpretative Guide to the UN Guiding Principles on Business and Human Rights' 14 (2012), https://www.ohchr.org/Documents/Issues/Business/ RtRInterpretativeGuide.pdf (accessed 29 September 2020).

9 Michael Barnett and Raymond Duvall, 'Power in International Politics' (2005) 59:1 International Organization 39, 42. $10 \quad$ Ibid, 44.

11 Max Weber, Economy and Society: An Outline of Interpretive Sociology (Berkeley: University of California Press, 1978).

12 This question is addressed in Peter Morriss, 'Steven Lukes on the Concept of Power' (2006) 4:2 Political Studies Review 124.
} 
The framework adopted herein defines four sites of corporate power over human rights: first, power over individuals; second, power over materialities; third, power over institutions; and fourth, power over knowledge. ${ }^{13}$ This captures that human rights are inherent in individuals and can be transgressed through direct interaction. It captures that all human rights, but particularly socio-economic rights, rest on a material foundation, and that corporations are economic actors with significant ability to interfere with this material foundation. It captures that human rights are legal standards and are implemented through governance structures that corporations may also influence. Finally, it captures corporate influence over the epistemic framework through which we understand human rights, including influence over the form, scope and limits of responsibility. The normative aim of this framework is to understand in totality how corporations may retrogress access to rights, structurally inhibit the realization of rights, and cause a range of impacts upon rights that have not traditionally been centred within BHR discourse, in order to better understand what it means, and what it takes, for a corporation to 'respect' human rights. ${ }^{14}$ This is not to claim that every potentially harmful interaction that corporations may have with human rights should be, or can be, prohibited. It is to claim that the only way to analyse whether such interactions should be prohibited or ameliorated is to start from the business actions themselves, rather than from the contingencies of legal, regulatory or corporate praxis.

The paper proceeds in section II with a brief description of the understanding of human rights adopted herein. Section III discusses theories of power. Section IV describes the framework itself, and section V provides examples of each element of power therein. The final section concludes.

\section{Human Rights}

There are many debates in human rights around justiciability, ${ }^{15}$ 'displacement', ${ }^{16}$ 'minimalism' ${ }^{17}$ and 'formative aims', 18 debates essentially around the limits of human rights law and practice. ${ }^{19}$ Such debates involve strategic restrictions on the scope of rights

\footnotetext{
13 The framework is predicated on 'where' corporations have power, rather than 'how'. The 'how' question - an understanding of how corporate power operates in these sites - is enabled by the prefigurative focus on these sites.

14 For detailed analysis of the term, see David Birchall, 'Any Act, Any Harm, To Anyone: The Transformative Potential of "Human Rights Impacts" Under the UN Guiding Principles of Business and Human Rights' (2019) 1:2 University of Oxford Human Rights Hub Journal 120; David Birchall, 'Irremediable Impacts and Unaccountable Contributors: The Possibility of a Trust Fund for Victims to Remedy Large-Scale Human Rights Impacts' (2019) 25:3 Australian Journal of Human Rights 428.

15 Aoife Nolan, Bruce Porter and Malcolm Langford, 'The Justiciability of Social and Economic Rights: An Updated Appraisal' in Menno T. Kamminga (ed.), Challenges in International Human Rights Law (London: Routledge, 2017), 89.

16 Paul O'Connell, 'Human Rights: Contesting the Displacement Thesis' (2018) 69:1 Northern Ireland Legal Quarterly 19

17 Joshua Cohen, 'Minimalism About Human Rights: The Most We Can Hope For?' (2004) 12:2 Journal of Political Philosophy 190; Eva Brems, 'Human Rights: Minimum and Maximum Perspectives' (2009) 9:3 Human Rights Law Review 349.

18 John Tasioulas, 'Minimum Core Obligations: Human Rights in the Here and Now', (Washington DC: World Bank, 2017), 5-8, https://openknowledge.worldbank.org/handle/10986/29144 (accessed 29 September 2020).

19 See Tom Campbell, Rights: A Critical Introduction (London: Routledge, 2011).
} 
for the purpose of enforceability or normative validity, while treaty rights and obligations contain their own limits. Herein, relevant rights are limited to those established by treaty law and applicable to business under the United Nations Guiding Principles on Business and Human Rights (UNGPs). ${ }^{20}$ Otherwise, the paper does not consider any strategic restrictions on the scope of these rights. This is to say that any business act that has an apparent effect on human rights constitutes a use of power over that right. Some acts, particularly, for example, those grounded in power over knowledge, may not be conceivable as breaches of specific responsibilities, but do nonetheless constitute a power that can impact rights. This allows the framework to capture the full extent of business-human rights interaction without concern for imposed limitations on responsibility. The possibilities that such an approach could then reflexively inform theories of responsibility and regulation are discussed in the conclusion.

This understanding of human rights is comparable to Thomas Pogge's, who states that ' $[\mathrm{t}$ ]he postulate of a human right to $\mathrm{X}$ is tantamount to the demand that, insofar as reasonably possible, any coercive social institutions be so designed that all human beings have secure access to $X^{\prime} \cdot{ }^{21}$ Taking this as a normative ideal, we can say that, ideally, corporations and the structures in which they operate should be designed so as to assist in human rights realization. This entails identifying the various means by which corporations can affect human rights, and particularly the ways in which corporate practices and the wider institutional environment are less than conducive to rights realization. This basic conception of human rights allows the research to centre human rights in a non-exclusionary manner.

This approach sees human rights as both the basis of minimal sufficiency and the realization of a good life. ${ }^{22}$ The progressive realization of these rights is social progress. Retrogressing access to rights is a sign of social decay. It is crucial in the era of globalization to understand and challenge the (new) ways in which realization may be inhibited and retrogression promoted. For example, each individual has a right to housing recognized in international law and under the UNGPs. ${ }^{23}$ This right is organized along seven core elements, including affordability and habitability. ${ }^{24}$ The right is realized within a jurisdiction when all individuals therein have secure access to housing along each of its seven elements. Because business is so involved in housing, numerous business acts can adversely impact this right, of which only a sliver constitute legal

\footnotetext{
20 The Guiding Principles list as the 'core internationally recognized human rights' the 'Universal Declaration of Human Rights and the main instruments through which it has been codified: the International Covenant on Civil and Political Rights and the International Covenant on Economic, Social and Cultural Rights), coupled with the principles concerning fundamental rights in the eight ILO core conventions as set out in the Declaration on Fundamental Principles and Rights at Work'. It adds that business enterprises may need to consider additional standards as elaborated in other UN instruments. The paper stays within these limits regarding the applicable human rights, without prejudice to the idea that some specific rights beyond these core doctrines may be significant and may be violated by corporations. OHCHR, note 7, Principle 12.

21 Thomas Pogge, World Poverty and Human Rights (Cambridge: Polity, 2008) 46.

22 This perspective is advanced in Wettstein, note 6, 100-9, particularly 107-9.

23 International Covenant on Economic, Social and Cultural Rights, UN Doc 973 UNTS 3I (adopted on 16 December 1966, entered into force 3 January 1976) note 7, Principle 12.

24 The UN Committee on Economic, Social and Cultural Rights (CESCR), General Comment No. 4: The Right to Adequate Housing (Art. 11 (1) of the International Covenant on Economic, Social and Cultural Rights), 13 December 1991, E/1992/23, para 8.
} 
breaches. ${ }^{25}$ Centring the right and its core elements allows us to encompass all impacts on access to the right, including through investments, lobbying, credit, speculation and data management. This generates a comprehensive view of the business-related impediments to realization which can then be used to reconsider rights-based responsibilities. What constitutes a 'blameworthy act', ${ }^{26}$ in Ruggie's terminology, depends on our understanding of rights, harm and corporate influence. ${ }^{27}$

\section{THEORIES OF POWER}

This section reviews the literature on power. Power studies developed from the fields of political science and international relations. A core tenet of realism as proposed by E.H. Carr was that the 'idealists' he critiqued ignored how (state) power operated and was instrumentalized. ${ }^{28}$ Carr's realist conception of power was primarily 'compulsory', or in different terminology, 'relational' or 'instrumental'. This is the direct, coercive use of power wherein one actor compels another to act in a way that is beneficial to the former. ${ }^{29}$ Kenneth Waltz updated realism in 1979 with his conception of neorealism, or structural realism, which focused on how international structures - notably the lack of global government, or international anarchy - directed actors down certain paths. ${ }^{30}$ Alexander Wendt later added the social constructivist rebuttal to the realists, arguing that anarchy exists but is malleable and is impacted by the subjectivities of actors toward it. ${ }^{31}$ Concurrently, Marxist and Gramscian-inspired scholars studied global power with a materialist focus on economic power. ${ }^{32}$ Liberal institutionalism, linked to global governance studies today, focused on the mediating power of global institutions and the potential for cooperation among actors. ${ }^{33}$ These conceptions (realist, constructivist, materialist and institutionalist) inform the delineation of forms of power herein. ${ }^{34}$

\footnotetext{
25 Human Rights Council, 'Report of the Special Rapporteur on adequate housing as a component of the right to an adequate standard of living, and on the right to non-discrimination in this context', A/HRC/34/51 (2017), http:// www.unhousingrapp.org/user/pages/04.resources/Thematic-Report-3-The-Financialization-of-Housing.pdf (accessed 24 September 2020).

26 Human Rights Council, 'Business and Human Rights: Mapping International Standards of Responsibility and Accountability for Corporate Acts', A/HRC/4/35 (19 February 2007), para 3.

27 This general topic is well treated in: Andrew Linklater, The Problem of Harm in World Politics: Theoretical Investigations (Cambridge: Cambridge University Press, 2011).

28 EH Carr, The Twenty Years' Crisis, 1919-1939: An Introduction to the Study of International Relations (London: Macmillan, 1939).

29 Robert Dahl, 'The Concept of Power' (1957) 2:3 Behavioral Science 201, 202-3.

30 Kenneth N Waltz, Theory of International Politics (Long Grove, IL: Waveland Press, 1979).

31 Alexander Wendt, 'Anarchy is What States Make of it: The Social Construction of Power Politics' (1992) 46:2 International Organization 391.

32 Robert W Cox, Production, Power, and World Order: Social Forces in the Making of History (New York: Columbia University Press, 1987).

33 Robert O Keohane, After Hegemony: Cooperation and Discord in the World Political Economy (Princeton University Press, 2005); Robert O Keohane, 'International Institutions: Two Approaches' (1988) 34:2 International Studies Quarterly 379.

34 Mikler, who studied corporate power from the perspective of international political economy, also starts from these delineations as ways of considering power. John Mikler, The Political Power of Global Corporations (Cambridge: Polity, 2018) 23-28.
} 
Power as a discrete object of analysis has, over the past century, developed through three major forms: relational, structural and discursive. Prior to Carr, Max Weber had defined power as 'the probability that one actor within a social relationship will be in a position to carry out his own will despite resistance'. ${ }^{35}$ Power was therefore defined as the ability to achieve desired outcomes. This relational view of power is concerned with the link between capabilities and goals. ${ }^{36}$ According to Morriss, it does not necessarily entail effects or influences upon other actors. ${ }^{37}$ This is problematic when focusing on power over human rights because the very aim is to link the corporate capacities of power with effects on human rights. Corporate power can harm human rights even when the goal is not achieved, such as damage occurring at the exploration stage of a mining project. ${ }^{38}$ Lukes, revising his previous conception, states that power should be defined 'in terms of agents' abilities to bring about significant effects'. ${ }^{39}$

Susan Strange studied structural power, defined as the power 'to decide how things shall be done, the power to shape frameworks within which states relate to each other, relate to people, or relate to corporate enterprises' ${ }^{40}$ A very simple example of structural power is that a government policy to prioritize roads over railways will dictate that more individuals own cars. Wettstein notes two forms of this power, which herein are termed 'market' and 'structural' power. ${ }^{41}$ Market power is the use of structural power to 'influence bargaining positions', for example, bargaining for favourable tax conditions when considering where to invest. ${ }^{42}$ This therefore utilizes market power imbalances to create more favourable conditions. This 'constitutes a hybrid position between structural and relational power' ${ }^{43}$ Structural power is the ability to determine outcomes because of a structural reality. ${ }^{44}$ For instance, the structural reality of corporate free movement allows companies freedom over their manufacturing locations. ${ }^{45}$ Here they do not need to bargain in order to manipulate conditions, rather, states are compelled to compete for their investment.

Later theorists, drawn from post-structuralism and constructivism, added discursive power, a meta-level power to shape discourse and social norms in one's favour, ${ }^{46}$ although with similarities to Strange's notion of a knowledge structure (below). Discursive power occurs where corporations can shape outcomes 'through promoting ideas, setting social norms and expectations, and even shaping identities.' ${ }^{47}$ Discourse,

\footnotetext{
Weber, note 11,53 .

36 See Wettstein, note 6, 193, for a discussion of emergent structuralism in the work of Max Weber.

37 Morriss, note 2, 30.

38 Daniela Chimisso Dos Santos and Sara L Seck, 'Human Rights Due Diligence and Extractive Industries', in David Birchall and Surya Deva (eds), Research Handbook on Human Rights and Business (Cheltenham: Edward Elgar, 2020).

39 Lukes, note 2, 65.

40 Strange, note 2, 25.

41 Wettstein, note 6, 194.

42 Ibid, 194.

43 Ibid, 195.

44 Ibid, 194.

45 Ruggie, note 6, 5.

46 Fuchs, note 5, 60.

47 Ruggie, note 6, 9.
} 
for Foucault, is the process of formation that occurs through language. Discourses produce fields of knowledge and set the boundaries of that knowledge. ${ }^{48}$ The conditions of truth within a historical period are determined discursively, defining what can and cannot be said, and who can speak on which topics authoritatively. ${ }^{49}$ Discursive power is particularly important therefore in interpreting situations and providing narrative structures, problems and apportioning blame. ${ }^{50}$ This is both the softest and perhaps the most pervasive form of power, wherein one exercises power 'by influencing, shaping or determining [another's] very wants' ${ }^{51}$ It is a form of power that 'does not simply pursue interests, but creates them' ${ }^{52}$ It is closely tied to legitimacy an actor seen as legitimate may be able to shape our understanding of a particular event or issue. $^{53}$

The relational-structural-discursive trichotomy has been challenged as an imprecise lens on power. Strange challenged her precursors who separated 'political' from 'economic' power, on the grounds that they are too interwoven. Political power relies on economic power, 'to purchase, to command production', and economic power relies on 'the sanction of political authority' ${ }^{54}$ However, the distinction between relational and structural power is also less than clear. Particularly, Strange is at times at risk of constructing structural power as an eternal given to contrast it with active, directed, relational power. She uses the Cold War example of US structural power over how wheat and corn were sold globally, which coerced even the Soviet Union into accepting the financialized technique. ${ }^{55}$ However, this structural power over the Soviet Union surely rested on the US's relational power. A change in relative power between the two would probably have led to either the Soviet Union's evasion or evisceration of this system. Structural power is contingent on relational, and other forms of structural, power. Discursive power is equally interlinked with the other elements, resting partially on the strength of argumentation, but also, inter alia, on the funding and political legitimacy of the organization. This is well explained by works in the Marxist tradition which reify the intersections between different forms of power. For example, while an employment contract is a legal relationship granting rights and responsibilities, social relations therein will shape the experience of employment, and over time legal, cultural and material evolutions will each play into how employment is experienced. ${ }^{56}$ To attempt to understand employment as a purely legal relationship is to miss the wider framework in which legal relations are vested.

\footnotetext{
48 Michel Foucault, 'Orders of Discourse' (1971) 10:2 Information (International Social Science Council) 7.

49 Nina Kolleck, 'How Global Companies Wield their Power', in John Mikler (ed.), The Handbook of Global Companies (Oxford: Wiley-Blackwell, 2013), 134.

50 Fuchs, note 5, 60.

51 Lukes, note 2, 23.

52 Fuchs, note 6, 61 .

53 Ibid, 61.

54 Strange, note 2, 25-26.

55 Ibid, 25, 82-84.

56 Karl Klare, 'Law-Making as Praxis' (1970) 40 Telos 123; Liam McHugh-Russell, 'Getting the Constitutive Power of Law Wrong', Legal Form (31 March 2018), https://legalform.blog/2018/03/31/getting-the-constitutive-power-of-lawwrong-liam-mchugh-russell/ (accessed 23 September 2020).
} 
This does not render the relational, structural, discursive delineation useless. Even if frequently interwoven in terms of the practice and effects of power, there is an evident divide that fits many actions. One can see a public relations campaign as an attempt to exercise discursive power, even if the likelihood of success rests on other forms of power, and note that this is distinct from achieving the same end through coercion. It does, however, mean that the delineation of examples of power over human rights into one of the tripartite forms may not be the most useful task, as an outcome, such as rights retrogression, will often involve a set of acts with elements of each form of power.

A more useful starting point may be Strange's definition of four power structures: security, production, finance and knowledge. These she describes as the four structures through which power operates in the contemporary political economy. ${ }^{57}$ Whoever controlled a structure within a particular circumstance could define how others behaved and define outcomes to a relevant degree. The four structures are derived from human need within economic, political and social spheres. ${ }^{58}$ Humans need security and the provider of that security exercises structural power over a range of areas, including, potentially, the extent of free movement and taxation. ${ }^{59}$ Productive power relates to what shall be produced, how, and by whom. It incorporates 'land, labour, capital and technology'. ${ }^{60}$ The financial structure relates to credit, but could incorporate a range of financial instruments today, which shape markets and lives. ${ }^{61}$ Finally, the knowledge structure relates to the power to create and reify knowledge within the global economy, and in a more constructivist vein, to the setting of social norms and popular discourses. ${ }^{62}$

\section{Corporate Power over Human Rights}

Barnett and Duvall drew from Strange and related works to develop the model that the framework herein borrows from most closely. As noted, Barnett and Duvall prioritize the capacity to cause effects, rather than the ability to achieve a desired outcome, and this is useful when examining power over human rights. ${ }^{63}$ They disaggregate power into compulsory, institutional, structural and productive elements to provide a comprehensive categorization of power in its totality. This merges Strange's use of delineated sites of power with the understandings of power developed in international relations literature, with 'compulsory' being related to the realist view of power, 'structural' to the Marxist view, and so on. This respects the major traditions of international relations, capturing their priorities to understand power in a comprehensive fashion. There is a key difference between the purpose of the framework herein and Barnett and Duvall's. Barnett and

\footnotetext{
Strange, note 2, 29-32.

Ibid, 29, 32 .

Ibid, 29.

Ibid, 29.

Ibid, 30.

Ibid, 31 .

Barnett and Duvall, note 9, 42.
} 
Duvall sought to understand 'Power in International Politics', encompassing the full gamut of actors and sites. This framework is more limited, focusing only on business actors and their power over human rights. Business has power over human rights insofar as it can influence, violate, retrogress, reshape, realize or restrict those rights.

It is argued that corporate power over human rights operates at four delineable sites: power over individuals, power over materialities, power over institutions, and power over discourse. The first is the direct, unmediated or weakly mediated power that corporations can wield over rights-holders. The next three are mediating sites through which corporate power can be used to affect human rights. Human rights are underlain by material foundations, whether land, supply of essential goods, personal wealth, or state funding, and therefore materialism is crucial. They are overarched by law and institutions that enforce and structure the rights. They are also affected at the meta-level by social norms which constitute knowledge around the right, most importantly the scope, limits and form of the responsibilities inherent therein. This captures realist, institutionalist, Marxist and constructivist priorities. ${ }^{64}$ The following paragraphs explain and justify each inclusion and their relationship to Barnett and Duvall's choices.

Barnett and Duvall define compulsory power as the 'range of relations between actors that allow one to shape directly the circumstances or actions of another' ${ }^{65}$ In the subheading this is simply 'direct control over another'. ${ }^{66}$ This is derived from a realist notion of 'pure' power, in which the more powerful actor can coerce the weaker actor. Their international relations framework focuses on major actors - states, multinational corporations, intergovernmental organizations. My framework focuses on the businesshuman rights relationship and I therefore narrow compulsory power to cover only direct power over individuals (including communities of individuals), the power to directly impact individuals' human rights. Corporations exercising 'compulsory' power over a state, for example (insofar as that is possible), would be mediating their power over human rights through the state, using the institution for their own ends and this is therefore placed in the 'institutional' category. The Barnett and Duvall definition is therefore altered to: 'the power that a corporation has to shape directly the human rights possibilities of individuals'. It is primarily a relational form of power, although one that necessarily utilizes extant structures, not least the employer-employee contractual relationship. It extends to de facto direct power over individuals such as through supply chains intermediaries. It also includes human rights violations, which we could term 'acute compulsory power' wherein the company has forcibly wronged an individual or group.

Second, power over materialities merges Strange's 'productive' and 'financial' structures and what Barnett and Duvall term 'structural power', concerning the role of structural positions (e.g. capital-labour) ${ }^{67}$ in constituting one's choices and possibilities. Within the framework herein, some such structural relationships are encompassed elsewhere, such as capital-labour as a direct power over individuals, and structural

\footnotetext{
64 Ibid, 43.

65 Ibid, 49.

66 Ibid, 49.

67 Ibid, 53.
} 
positions are equally important in a discursive sense. The framework itself pre-selects the relevant, albeit broad, structural positions of 'corporation' and 'rights-holder'. Barnett and Duvall focus on economic relations in this section following a Gramscian view of structuralism. ${ }^{68}$ I focus on one central element of corporate economic power, the role of materialities as a mediating site through which uneven power relationships are exploited. Ownership of materials - the means of production, distribution, land and finance - places corporations in a position to dictate access to rights. Power over materialities is thus defined as 'the mediated power that a corporation has to shape the human rights possibilities of individuals through control of material conditions or resources'. This definition captures three major areas: commodified or privatized rights; land and environment; and finance. Corporations exert an enormous amount of power through their control of material resources, and this control represents a crucial mediating structural relationship between corporation and rights-holder. Corporations control large parts of marketized socio-economic rights, including food, housing and sometimes healthcare, and can destabilize these markets. They control global finance and have singularly powerful effects on land resources and the environment. Rightsholders are often vulnerable to the effects of profit-motivated boardroom decisions taken with no malice toward them because the capacity of corporations to affect material outcomes is so significant, and because materialities are so central to rights realization. The role of corporations as economic actors with significant abilities to impact rights through their material power is a vital lens to reify within BHR.

Third is institutional power, which Barnett and Duvall define as the formal and informal institutions that mediate between $\mathrm{A}$ and $\mathrm{B}$, as $\mathrm{A}$, working through the rules and procedures that define those institutions, guides, steers, and constrains the actions - or nonactions - and conditions of existence of others. ${ }^{69}$ This is therefore power exercised through the medium of an institution. My definition follows their own: 'the mediated power that a corporation has to shape the human rights possibilities of individuals' through control of or influence over a governance institution'. This covers power within, over and through institutions. Institutions include states, inter-governmental organizations and non-governmental organizations. 'Governance' is defined broadly, to include not just state or international regimes but also the plethora of global governance institutions. This power may be exercised directly, in the form of lobbying for a legal or policy change, it may operate in the form of bargaining for conditions more favourable to the corporation, or it may involve formally taking control of a previously institutionalized function through privatization. As with lobbying, it does not necessitate true authority within an institution, but rather the ability to use the institution for its own purposes.

The fourth form is power over knowledge, most linked to Barnett and Duvall's 'productive power', ${ }^{70}$ defined as 'the constitution of all social subjects with various social powers through systems of knowledge and discursive practices of broad and

88 Ibid, 53-54.

69 Ibid, 51.

70 Ibid, 55. 
general social scope'. ${ }^{71}$ The focus is on 'systems of signification and meaning', including information, discourses and norms, not unlike Strange's 'knowledge structure'. ${ }^{72}$ Here they take the Foucauldian inspired move away from 'structures of subordination', as in 'structural power', toward the post-structuralist focus on meta-norms and culture. ${ }^{73}$ I define power over knowledge as: 'the power that a corporation has to shape knowledge of human rights and the wider epistemic framework in which human rights exist'. This therefore most directly incorporates the realm of social constructivism, social norms, discursive practices and intersubjective understandings. The basic idea underlying constructivism is that the way communities understand social life and events, even right and wrong, is shaped by shared understandings. For my purposes this refers specifically to the ability of corporations to reshape human rights-relevant knowledge. This includes the power to define their own human rights responsibilities, priorities, exclusions, and to influence the field of BHR. Discursive power readily seeps into interactions with other areas, while often not having clearly defined, visible impacts. For this reason, examples herein are focused on corporate acts that specifically and overtly shape knowledge around human rights, while also acknowledging the potential breadth of the paradigm.

Powerful actors can impact human rights in a litany of ways. This framework is designed to disaggregate these means into four forms to promote the systematic mapping of corporate impacts on human rights. It is submitted that every corporate interaction with human rights can be fitted into one of the four categories. The vision of human rights that this creates is one in which the individual is at the centre of a universe underlain by material conditions, overarched by governance, and encircled by discourses and knowledge construction that shape the possibilities for each. The framework can be demonstrated simply through four examples related to wealth. A corporation can adversely impact the human rights of individuals directly by cutting or not paying wages, potentially restricting the ability of individuals to ensure their own human rights. A corporation that avoids tax reduces the amount of money available to the government to protect rights, thus impacting the material base underlying rights through a structural power derived from the reality of economic globalization. A corporation that lobbies the government to lower tax rates in return for investment has used the institution of the state in a way that may cause adverse impacts. A corporation that funds research into the drawbacks of universal healthcare may encourage funding cuts to healthcare, risking human rights impacts through shaping discourse. In each case the effect of reduced spending to guarantee human rights is similar, but the site of the effect is distinct.

As noted regarding discursive power, there will always be potential overlaps within these delineations. Institutions play a role in every BHR interaction, whether permissive, facilitating, incentivizing or prohibitive. The corporation is a creation of the state and is

\footnotetext{
71 Martha Finnemore and Kathryn Sikkink, 'Taking Stock: The Constructivist Research Program in International Relations and Comparative Politics' (2001) 4:1 Annual Review of Political Science 391, 393.

72 Barnett and Duvall, note 9, 56.

73 Ibid, 56.
} 
shaped by its laws and legal gaps. ${ }^{74}$ Control of a materiality can create a very direct relationship between business and the individual, as in the landlord-tenant relationship. However, disaggregating these four sites, even allowing for potential overlaps, opens space to reconsider the BHR spectrum according to these distinctive sites. It promotes consideration of the human rights impacts of the pure economic activity of corporations, of corporate institutional influence, and of corporate discourse. Acts such as tax avoidance, lobbying and promoting a self-serving version of one's own human rights responsibilities are not human rights violations, but they can affect human rights, and they can suggest that the company in question does not respect human rights in a comprehensive sense. If a central aim within BHR is to create corporations that respect human rights, it is vital to understand the role that every facet of corporate activity plays in respecting or disrespecting rights, and to not allow some harmful activities to slip by because they are beyond a pre-ordained scope. By making each area visible, it also allows for linkages between the sites to be identified, for example seeing how lobbying can lead to more hegemonic control of a materiality, which then creates the conditions for overtly harmful direct interactions.

The key ambition is to link corporate acts to their effects on human rights. The framework provides a disaggregated means by which to do this. Next, the paper illustrates each form of power with three examples, each showing a different form of the specific power, and totalling 12 very brief case studies of corporate power over human rights. These are, naturally, just a selection of examples rather than the entire picture. Nothing in this article should be read as implying that business is all powerful in any sector. Rather, the supposition is that businesses can and do have impacts in each area. The examples should be read descriptively rather than normatively, despite the focus on harm. In some cases, corporate power may be seen as assisting in the creation of a middle ground in a still developing field, such as when corporations define their own responsibilities. In other cases, one may feel that corporate activity provides totalized benefits. This could be the case with supply chain labour, for example. This is not therefore meant to necessarily condemn each form in its totality, but to describe it, simply, as a power over human rights and to illustrate with examples the harmful uses of these powers.

\section{A. Power over Individuals}

Power over individuals is the most likely to include overt compulsory power. It comprises the direct interactions that occur between corporations, including managers, and individuals. It includes the majority of the legal, regulatory and soft law areas of BHR, including any business harm to human rights that could be considered justiciable. However, it also includes many human rights-related areas that are not central to BHR. This section describes three forms of power over individuals that cause, or have the potential to cause, human rights impacts, covering direct violations, the primarily

\footnotetext{
74 Mikler, note 50, 31-32; fully explored in Katharina Pistor, The Code of Capital: How the Law Creates Wealth and Inequality (Princeton: Princeton University Press, 2019).
} 
structural power to reshape employment opportunities, and the primarily discursive power to incentivize harmful choices through marketing.

First, the power to violate an individual's human rights includes everything from killing to privacy violations, criminal to tortious wrongs, labour rights violations, and so on. ${ }^{75,76}$ This is an exercise of compulsory power by a corporation upon an individual or group. Such cases are defined by a wrongful act being committed against the will of the victim. The corporation must either actively commit the wrong or breach a duty of care. Access to remedy through grievance mechanisms generally relies on an individual or group demonstrating that a specific corporation acted so as to breach their rights, causing a specific harm. ${ }^{77}$ This is therefore the most direct type of impact a corporation can have on an individual's rights. This area also constitutes a major focal point of the BHR field.

Second, businesses as employers have the power to directly impact employees. One example is the restructuring of employment to form the emergent 'precariat', constituted by new forms of insecure, temporary and poorly paid work. ${ }^{78}$ Corporations cannot compel individuals to take on such work, but they can create a system - with and through law - in which individuals are forced to choose such options. In human rights terms, conditions of just work are retrogressed by business actions, ${ }^{79}$ a situation which in theory creates pro tanto obligations upon states to protect against this retrogression. ${ }^{80}$ This restructuring of the labour markets puts individuals in a position where their rights cannot be fulfilled due to a combination of low pay, irregular hours and shortterm contracts. Companies constituting the 'gig economy' such as Uber, are prevalent examples of such firms, while other industries are adopting similar models. ${ }^{81}$ A majority of academics, for example, in both the UK and Australia are on zero-hour or short-term contracts. ${ }^{82}$ Individuals may be unable to realize other rights due to precarity (such issues

75 See Surya Deva, Regulating Corporate Human Rights Violations: Humanizing Business (London: Routledge, 2012).

76 Robert McCorquodale and Penelope Simons, 'Responsibility Beyond Borders: State Responsibility for Extraterritorial Violations by Corporations of International Human Rights Law' (2007) 70:4 The Modern Law Review 598; Opi Outhwaite and Olga Martin-Ortega, 'Human Rights in Global Supply Chains: Corporate Social Responsibility and Public Procurement in the European Union' (2016) 10:1 Human Rights \& International Legal Discourse 41; Daniel Augenstein, 'Torture as Tort? Transnational Tort Litigation for Corporate-Related Human Rights Violations and the Human Right to a Remedy’ (2018) 18:3 Human Rights Law Review 593.

77 Sarah Knuckey and Eleanor Jenkin, 'Company-Created Remedy Mechanisms for Serious Human Rights Abuses: A Promising New Frontier for the Right to Remedy?' (2015) 19:6 The International Journal of Human Rights 801; Mariëtte van Huijstee and Joseph Wilde-Ramsing, 'The Relationship Between Non-Judicial Grievance Mechanisms and Access to Remedy for Business-Related Human Rights Abuses' in David Birchall and Surya Deva (eds.), Research Handbook on Human Rights and Business (Cheltenham: Edward Elgar, 2020).

78 Guy Standing, The Precariat: The New Dangerous Class (Oxford: Bloomsbury Publishing, 2011).

79 The UN Committee on Economic, Social and Cultural Rights (CESCR), General Comment No. 23 (2016) on the right to just and favourable conditions of work (Article 7 of the International Covenant on Economic, Social and Cultural Rights), 7 April 2016, E/C.12/GC/23, para 47(d), https://www.refworld.org/docid/5550a0b14.html (accessed 24 September 2020).

80 Christian Courtis, Nicholas Lusiani and Aoife Nolan, 'Two Steps Forward, No Steps Back? Evolving Criteria on the Prohibition of Retrogression in Economic and Social Rights' in Aoife Nolan (ed.), Economic and Social Rights after the Global Financial Crisis (Cambridge: Cambridge University Press, 2014), 116.

81 Gary Hall, The Uberfication of the University (University of Minnesota Press, 2016).

82 Thomas Allmer, 'Zero-Hour Contracts are Turning University Lecturers Off the Job', The Conversation (17 September 2017), http://theconversation.com/zero-hour-contracts-are-turning-university-lecturers-off-the-job74949 (accessed 24 September 2020). In Australia 43 per cent are employed on a casual basis, while 22 per cent are engaged on a fixed-term contract. See Kate Cantrell and Kelly Palmer, 'The Casualties of Academia: A Response to The 
invoke inter-related responsibilities of government), ${ }^{83}$ or suffer adverse mental or physical health impacts from the stress. ${ }^{84}$ The problem is rooted in a structural power: businesses have few jobs or contracts to distribute and therefore businesses are able to gradually reduce the pay, security and benefits that go with a job. Automation threatens to exacerbate this problem. ${ }^{85}$ Relatedly, private companies can surveil and discipline workers in new ways, marking worrying inroads into privacy rights and causing health impacts. ${ }^{86}$ Companies have adopted a range of tactics bearing similarities with Bentham's Panopticon, the effect of which was to 'induce in the inmate a state of conscious and permanent visibility that assures the automatic functioning of power'. ${ }^{87}$ One company photographs its remote workers through their laptop camera every ten minutes. ${ }^{88}$ Private chat messages are routinely monitored, ${ }^{89}$ as is employee movement. ${ }^{90}$ Amazon warehouses monitor workers' productivity rates along multiple variables to allow them to be pushed to, and often beyond, the limit. ${ }^{91}$ Such innovations place the workers under extreme stress. In the US, 'from October 2013 to October 2018, authorities responded to 911 calls at least 189 times for suicide attempts, suicidal thoughts, and other mental-health episodes at Amazon warehouses.' 92

A final example relates to marketing to vulnerable individuals. One example of an 'adverse human rights impact' provided for in the UNGPs is that of '[t]argeting highsugar foods and drinks at children, with an impact on child obesity.' ${ }^{3}$ Corporate discursive power, here mobilized through advertising, is used to tempt, perhaps to coerce, vulnerable individuals into making lifestyle choices detrimental to their own health and beneficial to corporate profits. A similar, infamous case is that of Nestlé's breastmilk substitute advertising in developing countries, ${ }^{94}$ as well as the for-profit

Conversation', Overland (6 May 2019), https://overland.org.au/2019/05/the-casualties-of-academia-a-response-to-theconversation/ (accessed 24 September 2020).

83 Craig Gundersen and James P Ziliak, 'Food Insecurity and Health Outcomes' (2015) 34:11 Health Affairs 1830.

84 Zuzana Řimnáčová and Alena Kajanová, 'Stress and the Working Poor' (2019) 29:1 Human Affairs 87.

85 Richard B Freeman, 'Who Owns the Robots Rules the World' (2015) 5 IZA World of Labor 1.

86 Also relevant here is power over data, as social media companies hold.

87 Michel Foucault, Discipline and Punish: The Birth of the Prison (New York: Vintage, 2012) 201.

88 Olivia Solon, 'Big Brother Isn't Just Watching: Workplace Surveillance Can Track Your Every Move', The Guardian (6 November 2017), https://www.theguardian.com/world/2017/nov/06/workplace-surveillance-bigbrother-technology (accessed 24 September 2020).

89 Ellen Sheng, 'Employee Privacy in the US is at Stake as Corporate Surveillance Technology Monitors Workers' Every Move', CNBC (15 April 2019), https://www.cnbc.com/2019/04/15/employee-privacy-is-at-stake-as-surveillancetech-monitors-workers.html.

90 Ceylan Yiginsu, 'If Workers Slack Off, the Wristband Will Know. (And Amazon Has a Patent for It.)' New York Times (1 February 2018), https://www.nytimes.com/2018/02/01/technology/amazon-wristband-tracking-privacy.html (accessed 24 September 2020).

91 Michael Sainato, 'Revealed: Amazon Employees are Left to Suffer After Workplace Injuries', The Guardian, 2 April 2019, https://www.theguardian.com/technology/2019/apr/02/revealed-amazon-employees-suffer-after-workplaceinjuries (accessed 24 September 2020).

92 Max Zahn, “Colony of Hell': 911 Calls From Inside Amazon Warehouses', The Daily Beast (8 May 2019), https:// www.thedailybeast.com/amazon-the-shocking-911-calls-from-inside-its-warehouses (accessed 24 September 2020).

93 OHCHR, note 8, 17.

94 James Post, 'Assessing the Nestlé boycott: Corporate Accountability and Human Rights' (1985) 27:2 California Management Review 113. 
promotion of both dangerous beauty standards and of gambling. In each case, vulnerable individuals are exploited in ways that, as the UNGPs note, fit the definition of adverse human rights impacts. While there is an element of personal choice in such cases, corporations spend vast amounts attempting to reconstruct these choices in ways beneficial to profits, and sometimes harmful to individuals.

\section{B. Power over Materialities}

Materialities relate to the underlying material conditions on which rights rely. Corporate acts regularly impact these conditions. Herein I use material examples of housing, finance and the environment. Each represents a structural business power constituted through control of the mediating resource through which businesses reshape the possibilities for rights realization of individuals, often boosted by their influence over institutions and discourses to reify and legitimize this power.

Commodified human rights such as food, housing and aspects of healthcare are an obvious source of power over materialities. Commodification necessitates that, to some extent, market actors dictate the structural conditions of the human right. In most jurisdictions housing is primarily organized privately and for profit. The free market approach grants corporations power to profit from adverse impacts. In many major cities the affordability of housing is retrogressing with consequent effects on aspects such as habitability and location. ${ }^{95}$ Prices in Hong Kong, London, Munich and many other cities have 'increased by over 50 per cent since 2011 '.${ }^{96}$ Lower-income individuals are often forced out of these cities, ${ }^{97}$ or forced into often squalid, miniscule apartments lacking basic amenities. ${ }^{98}$ The UN Special Rapporteur (UNSR) on the right to housing tied this problem to business actors, stating that corporations use housing as a 'safety deposit box', investing particularly in already-inflated major cities safe in the knowledge value that will accrue. ${ }^{99}$ In Ireland, Australia and Hong Kong, corporations practise various forms of land-hoarding to keep prices high. ${ }^{100}$ The investment firm Blackstone has become the world's largest private landlord and is accused of exploiting every possible loophole to drive up tenancy costs and weaken protections. ${ }^{101} \mathrm{New}$, more exploitative contract forms are frequently developed. ${ }^{102}$ Businesses, assisted by laws conducive to business, ${ }^{103}$ have transformed housing from a social good into a commodity. This business control over

\footnotetext{
95 The UN Committee on Economic, Social and Cultural Rights (CESCR), note 24, para 8.

96 UN Special Rapporteur (UNSR), note 25, para 26.

97 Michael Edwards, 'The Housing Crisis and London' (2016) 20:2 City 222.

98 Luke Marsh, 'The Strategic Use of Human Rights Treaties in Hong Kong's Cage-Home Crisis: No Way Out?' (2016) 3:1 Asian Journal of Law and Society 159.

99 UN Special Rapporteur (UNSR), note 25, para 25.

100 David Birchall, 'Constructing Clear Violations of Commodified Human Rights: The Case of the Right to Housing' (2020) 19:1 Santa Clara Journal of International Law 1.

101 'Mandates of the Working Group on the issue of human rights and transnational corporations and other business enterprises and the Special Rapporteur on adequate housing as a component of the right to an adequate standard of living, and on the right to non-discrimination in this context', OL OTH 17/2019 (22 March 2019).

102 Joshua Akers, Eric Seymour, Diné Butler and Wade Rathke, 'Liquid Tenancy: "Post-Crisis" Economies of Displacement, Community Organizing, and New Forms of Resistance' (2019) 1:1 Radical Housing Journal 9-11.

103 David Birchall, 'Human Rights on the Altar of the Market: the Blackstone Letters and the Financialisation of Housing' (2019) 10:3-4 Transnational Legal Theory 446, 467-468; Ingrid Leijten and Kaisa de Bel, 'Facing
} 
housing creates demonstrable effects in terms of rising prices, rising debt and rising homelessness, ${ }^{104}$ each of which are expressible as breaches of fundamental elements of the right to housing. ${ }^{105}$

Finance provides a second area through which the materialities of rights can be impacted. Corporations have power over the structures of global finance, as individual actors have means within this structure by which they can profit from harm. ${ }^{106}$ One of the most critical problems related to finance today is that of tax avoidance and tax evasion. 'The equivalent of $10 \%$ of global GDP is held offshore by rich individuals in the form of bank deposits, equities, bonds and mutual fund shares, most of the time in the name of faceless shell corporations, foundations and trusts.' 107 'Six European tax havens alone (Luxembourg, Ireland, the Netherlands, Belgium, Malta and Cyprus) siphon off a total of $€ 350$ bn every year.' 108 'Tax havens deprive the EU of the equivalent of a fifth of the corporate tax revenue it currently collects. This represents a cost of $€ 60 \mathrm{bn}$ per a year.' 109 Wealth concealment deprives governments globally of about $€ 155 \mathrm{bn}$ a year in revenue. ${ }^{110}$ One of the most damaging forms of tax avoidance in the developing world is transfer mispricing. This accounts for 60 per cent of tax avoidance in Africa. A corporation working in a developing country sells a major product at an artificially low price to a subsidiary in a tax haven. The subsidiary then sells the product at the market price, thereby avoiding most tax. State-owned mines in the Democratic Republic of Congo (DRC) were sold to anonymous shell companies in the Virgin Islands this way. ${ }^{111}$ This "cost the DRC US $\$ 1.35$ billion, which is twice the education and health budget of a country where $71.3 \%$ of the population currently lives below the poverty line.' ${ }^{112}$ Tax avoidance reduces the ability of states to protect rights. ${ }^{113}$ Magdalena Sepúlveda Carmona, as UNSR on extreme poverty and human rights, states that tax avoidance breaches the responsibility to respect, 'insofar as [it has] a negative human rights impact'. ${ }^{114}$ Tax avoidance is a good example of corporate power over human rights

Financialization in the Housing Sector: A Human Right to Adequate Housing For All' (2020) 38:2 Netherlands Quarterly of Human Rights 9.

104 Birchall, note 100.

105 Ibid.

106 Centre for Economic and Social Rights, 'From Disparity to Dignity: Tackling Economic Inequality Through the Sustainable Development Goals', Centre for Economic and Social Rights Human Rights Policy Brief (2016), https:// www.cesr.org/sites/default/files/disparity_to_dignity_SDG10.pdf (accessed 29 September 2020).

107 Gabriel Zucman, 'The Desperate Inequality Behind Global Tax Dodging', The Guardian (8 November 2017), https://www.theguardian.com/commentisfree/2017/nov/08/tax-havens-dodging-theft-multinationals-avoiding-tax? CMP=Share_AndroidApp_Gmail (accessed 24 September 2020).

108 Ibid.

109 Ibid.

110 Ibid.

111 Isabella Mosselmans, 'Tax Evasion: The Main Cause of Global Poverty', LSE Blogs (7 March 2014), http:// blogs.lse.ac.uk/africaatlse/2014/03/07/tax-evasion-the-main-cause-of-global-poverty/ (accessed 24 September 2020). 112 Ibid.

113 Shane Darcy, “"The Elephant in the Room”: Corporate Tax Avoidance and Business and Human Rights' (2016) 2:1 Business and Human Rights Journal 1, 23.

114 Human Rights Council, 'Report of the Special Rapporteur on extreme poverty and human rights, Magdalena Sepúlveda Carmona', A/HRC/26/28 22 May 2014), para 7. 
because while it is not a direct breach of a specific human rights rule it provably weakens the socio-economic base needed to protect human rights with inevitable, severe consequences for human rights realization. ${ }^{115}$

A third material element is that of land and the environment. Corporate activity causes severe harmful effects on land and the environment, from the compulsive, in the form of land acquisition, to the structural, through the literal reconstituting of land through climate change causing flooding and drought. Many BHR-related legal cases stem from environmental issues, ${ }^{116}$ and the risks go beyond what is currently justiciable. Corporations are the primary producers of carbon dioxide and other pollutants causing air pollution and associated health problems, ocean acidification and climate change. Climate change is a major global issue today, and therefore business responsibility is more advanced. ${ }^{117}$ The OHCHR has stated that businesses should be held 'accountable for their climate impacts', ${ }^{118}$ and John Knox, the UNSR on Human Rights and the Environment, has elaborated business responsibilities related to climate change. ${ }^{119}$ Many severe human rights impacts can be traced to climate change, not least for those in low-lying areas who face serious risks to their rights to life, food, health and numerous concomitant impacts. ${ }^{120}$ Big companies, from oil to manufacturing to transport, are driving these dangerous changes, re-shaping communities that they will never meet.

\section{Power over Institutions}

This section contains three brief examples designed to map different levels of power over institutions. These are lobbying, a primarily relational power to influence a state; the structural power of free-moving capital's advantages over jurisdictionally bounded states; and privatization, which flows from social norms, structures and relational bargaining.

Lobbying is a relational power that corporations can have over states. It may be used for a single purpose or may be industry-wide and ongoing. An example of the latter is US healthcare. US companies have a responsibility to respect the right to health under the

\footnotetext{
115 The UNGPs (Principle 11) do state that 'Business enterprises should not undermine States' abilities to meet their own human rights obligations', but there is no consensus on this implicating any level of tax compliance; David Birchall, 'The Consequentialism of the UN Guiding Principles on Business and Human Rights: Towards the Fulfilment of "Do No Harm”" (2019) 24:1 Journal of Business Ethics and Organization Studies 28.

116 For example, Tara Van Ho, 'Vedanta Resources Plc and Another v. Lungowe and Others' (2020) 114:1 American Journal of International Law 110.

117 Sara Seck, 'Revisiting Transnational Corporations and Extractive Industries: Climate Justice, Feminism, and State Sovereignty' (2016) 26 Transnational Law \& Contemporary Problems 383.

118 OHCHR, 'Understanding Human Rights and Climate Change', (26 November 2015), para 8, http:// www.ohchr.org/Documents/Issues/ClimateChange/COP21.pdf (accessed 24 September 2020).

119 John Knox, 'Report of the Special Rapporteur on the Issue of Human Rights Obligations Relating to the Enjoyment of a Safe, Clean, Healthy and Sustainable Environment: Climate Change', A/HRC/31/52 (2016), para 66, www.ohchr.org/EN/Issues/Environment/SREnvironment/Pages/Annualreports.aspx (accessed 24 September 2020); John Knox, 'Report of the Special Rapporteur on the Issue of Human Rights Obligations Relating to the Enjoyment of a Safe, Clean, Healthy and Sustainable Environment: Report to the General Assembly', A/73/188 (19 July 2018), para 18, http://srenvironment.org/sites/default/files/Reports/2018/Boyd\%20Knox\%20UNGA\%20report\% 202018.pdf (accessed 24 September 2020).

120 Sandra McCubbin, Barry Smit and Tristan Pearce, 'Where Does Climate Fit? Vulnerability to Climate Change in the Context of Multiple Stressors in Funafuti, Tuvalu' (2015) 30 Global Environmental Change 43.
} 
UNGPs despite the ICESCR not being ratified in the US. ${ }^{121}$ Since 2007, over \$3billion dollars has been spent annually in the US by lobbyists, almost all by business. ${ }^{122}$ Health topped the list in 2016, with finance, electronics and energy - all industries fighting ongoing political battles - close behind. ${ }^{123}$ Pharmaceutical Research and Manufacturers of America (PhRMA), the American Hospital Association, the American Medical Association and Blue Cross/Blue Shield (a health insurance firm) make up four of the top seven spots over the last twenty years, each with over $\$ 300$ million in total expenditure. ${ }^{124}$ Purdue Pharma is one of the corporations most tied to the opioid epidemic, and gives around $\$ 1$ million per year to politicians. ${ }^{125}$ This epidemic is blamed in part on the huge volume of prescription drugs handed out by doctors, working for private health companies. ${ }^{126}$ Other problems in US healthcare stem directly from costs. One famous case is that of Martin Shkreli, whose firm increased the price of the drug Daraprim from $\$ 13.50$ a pill to $\$ 750$ a pill in $2015 .{ }^{127}$ Other cases include Harvoni, a hepatitis $\mathrm{C}$ drug, that costs $\$ 10,000$ more in the US than anywhere else, while cancer drug Avastin costs three times the next highest price globally. ${ }^{128}$ Costs for emergency treatments are also significant, with the growth of 'facility fees', fees charged to attend emergency rooms, a recent issue. One patient with a back problem was charged $\$ 3.50$ for a muscle relaxant and $\$ 2,426.34$ in facility fees. ${ }^{129}$ Another paid $\$ 629$, of which $\$ 7$ was for a Band-Aid and the rest in facility fees. ${ }^{130}$ These fees have wider impacts, such as medical bills being the single largest cause of consumer bankruptcy, at between 18 and 25 per cent of cases. ${ }^{131}$ Minorities and children are disproportionately uninsured. ${ }^{132}$ Through lobbying, corporations are able to exercise relational power over politicians,

\footnotetext{
121 UNGPs, note 7, Principle 23, states that 'all business enterprises have the same responsibility to respect human rights wherever they operate'.

122 Erin Duffin, 'Total Lobbying Spending in the United States from 1998 to 2016', Statistica (4 March 2020), https:// www.statista.com/statistics/257337/total-lobbying-spending-in-the-us/ (accessed 24 September 2020).

123 Erin Duffin, 'Total Lobbying Expenses in the United States in 2016, by Sector', Statistica (4 March 2020), https:// www.statista.com/statistics/257368/total-lobbying-expenses-in-the-us-by-sector/ (accessed 24 September 2020).

124 Center for Responsive Politics, 'Top Spenders All Years 1998-2018', https://www.opensecrets.org/lobby/top.php? showYear=a\&indexType $=\mathrm{s}$ (accessed 24 September 2020).

125 Center for Responsive Politics, 'Purdue Pharma', https://www.opensecrets.org/lobby/clientsum.php?id= D000022208 (accessed 29 March 2020).

126 Karin Ann Mack, Christopher McCall Jones and Roderick John McClure, 'Physician Dispensing of Oxycodone and Other Commonly Used Opioids, 2000-2015' (2017) Pain Medicine.

127 Carolyn Johnson, 'What Happened to the $\$ 750$ Pill that Catapulted Martin Shkreli to Infamy', Washington Post (1 August 2017), https://www.washingtonpost.com/news/wonk/wp/2017/08/01/what-happened-to-the-750-pill-thatcatapulted-pharma-bro-martin-shkreli-to-infamy/?utm_term=.012f91332alb (accessed 24 September 2020).

128 Sarah Kliff and Soo Oh, 'America's Health Care Prices are Out of Control. These 11 Charts Prove It', Vox (10 May 2018, https://www.vox.com/a/health-prices (accessed 24 September 2020).

129 Sarah Kliff, 'Emergency Rooms are Monopolies. Patients Pay the Price', Vox, 4 December 2017, https:// www.vox.com/health-care/2017/12/4/16679686/emergency-room-facility-fee-monopolies (accessed 24 September 2020).

130 Sarah Kliff, 'The Case of the \$629 Band-Aid - and What it Reveals About American Health Care', Vox, 13 May 2016, https://www.vox.com/2016/5/13/11606760/emergency-facility-fees-american-health-care (accessed 24 September 2020).

131 Department for Professional Employees (DPE), 'The U.S. Health Care System: An International Perspective', Fact Sheet (2016), https://dpeaflcio.org/programs-publications/issue-fact-sheets/the-u-s-health-care-system-an-internationalperspective/ (accessed 24 September 2020).

132 Ibid.
} 
in so doing answering key questions related to the right to health in favour of corporate interests, and contributing to systemic adverse impacts upon access to health in the US.

Second, corporations have power over human rights from their structural position as free-moving actors contrasted with that of jurisdictionally bounded states. States require investment and jobs that corporations provide and therefore corporations have, in aggregate, the power to coerce pro-business policies. Benvenisti puts this in terms of a 'global prisoner's dilemma', in which states are aware that they are trading away their resources, rights and democracy, but can do nothing to stop it. ${ }^{133}$ One institutionalized element of this relationship is the investor-state dispute settlement, wherein companies are granted the right to sue governments for breaching agreements. ${ }^{134}$ Supply chains, particularly in manufacturing, are one example of the power of transnational capital and the competitive nature of the modern state. This power is partly grounded in a direct power over individuals with similar dynamics to that of the precariat, but also in more comprehensive powers over the state to coerce favourable policies. Developing states with labour surpluses want to become manufacturing hubs, and the most important metric on which to compete is price. Although there are several regulatory initiatives covering supply chain factories, ${ }^{135}$ workers and states are trapped in a system where new, cheaper labour markets keep entering, most recently Myanmar and Ethiopia. ${ }^{136}$ This creates conflicting pressures on costs. Unions in Cambodia state that the current minimum wage level 'does not allow workers to live with dignity', yet from the business perspective it 'makes it a challenge for Cambodia to stay competitive.' ${ }^{137}$ In Bangladesh, garment factories pay only 15 per cent tax, significantly lower than most sectors, to help them compete. ${ }^{138}$ The need to attract investment minimalizes the developmental gains of investment, impacting rights from the right to just work to the right to life. ${ }^{139}$ This market structuring power, while a root cause of rights non-realization, does not feature in individualized business responsibilities, because no company is to blame for the market reality. It is nonetheless a system rife with exploitations and violations, from pay to sexual abuse and that hinders comprehensive rights realization.

Finally, corporations can be granted power over a human right by a state through privatization. Fuchs notes that this 'reflects the acquisition of discursive power by business because it demonstrates a change in attitude toward the market and market

\footnotetext{
133 Eyal Benvenisti, 'Exit and Voice in the Age of Globalization' (1999) 98:1 Michigan Law Review.

134 Stephen Schill, 'Reforming Investor-State Dispute Settlement (ISDS): Conceptual Framework and Options for the Way Forward', Geneva: International Centre for Trade and Sustainable Development/World Economic Forum (2015).

135 Justine Nolan, 'Business and Human Rights: The Challenge of Putting Principles into Practice and Regulating Global Supply Chains' (2017) 42:1 Alternative Law Journal 42.

136 Cornelia Staritz and Lindsay Whitfield, 'Made in Ethiopia: The Emergence and Evolution of the Ethiopian Apparel Export Sector', Center of African Economies Working Paper 2017: 3, https:/typo3.ruc.dk/fileadmin/assets/isg/02_ Forskning/CAE/CAE_WP3_Staritz_and_Whitfield.pdf (accessed 24 September 2020).

137 Prak Chun Thul, ‘Cambodia Hikes Textile Workers' Minimum Wage, Falls Short of Union Demands', Reuters, (5 October 2018), https://www.reuters.com/article/us-cambodia-garment/cambodia-hikes-textile-workers-minimumwage-falls-short-of-union-demands-idUSKCN1MF18B (accessed 24 September 2020).

138 KPMG, 'Bangladesh Taxation' (February 2018), https://home.kpmg/xx/en/home/insights/2018/02/bangladeshvat-law-tax-holidays-corporate-tax-rate-changes.html (accessed 24 September 2020).

139 Shamima Akhter, 'Endless Misery of Nimble Fingers: The Rana Plaza Disaster' (2014) 20:1 Asian Journal of Women's Studies 137.
} 
actors that has allowed business to obtain political authority.' ${ }^{140}$ This is a similar root to self-regulation, wherein again the corporation is granted specific authority. ${ }^{141}$ Privatization is an accepted means by which states may choose to fulfil their human rights obligation but carries risks. ${ }^{142}$ In General Comment 24, the CESCR describes privatization as '[posing] new challenges... [p]rivatization is not per se prohibited [but should] be subject to strict regulations... this may include requirements concerning universality of coverage and the continuity of the service, pricing policies, quality requirements, and user participation.' ${ }^{143}$ One of the most contentious areas of privatization is security, prisons and immigration management. G4S has been criticized for its running of Brook House Immigration Removal Centre in the UK, where 'widespread self-harm and attempted suicides' were discovered, with obvious rights implications. ${ }^{144} \mathrm{G} 4 \mathrm{~S}$ is also facing lawsuits for its role in the well-documented conditions on Manus Island, part of Australia's immigration detention system. ${ }^{145}$ Returning to Fuchs' notion of 'political authority' it is worth noting that the greater involvement a firm like G4S has in running detention centres, the more expert and legitimate its views may appear to governments. This will shape some big decisions, such as whether violence by a detainee is treated with confinement and loss of privileges or by providing social care. G4S's desire for profit may in turn shape its choice of recommendations.

\section{Power over Knowledge}

Finally, corporations have power over knowledge and norms within human rights. Here the effects on human rights themselves will be a product of the knowledge produced therein. This area of power is fundamentally distinct from the others because it often cannot be linked to any outcome that could be termed a human rights impact or any other form of breach. It is primarily a power to re-define the scope of their responsibilities and to legitimize corporations as human rights actors. Related forms include power over information related to rights, such as the allegation that Facebook's algorithm helped stoke anti-Rohingya feelings in Myanmar, ${ }^{146}$ and the power to reshape wider discourses, such as the Koch Brothers' longstanding research, public relations and campaigning agenda into libertarian politics in the US. ${ }^{147}$ This section focuses on three issues: at the

\footnotetext{
140 Fuchs, note 5, 64.

141 Wettstein, note 6, 250-2.

142 Aoife Nolan, 'Privatization and Economic and Social Rights' (2018) 40:4 Human Rights Quarterly 815, 818.

143 The UN Committee on Economic, Social and Cultural Rights (CESCR), General Comment No. 24 (2017) on State Obligations Under the International Covenant on Economic, Social and Cultural Rights in the Context of Business Activities, 10 August 2017, E/C.12/GC/24, para 21, https://www.refworld.org/docid/5beaecba4.html (accessed 24 September 2020).

144 'Detainees "Mocked and Abused" at Immigration Centre', BBC (1 September 2017, https://www.bbc.com/news/uk-41121692 (accessed 24 September 2020).

145 Gabrielle Holly, 'Transnational Tort and Access to Remedy under the UN Guiding Principles on Business and Human Rights: Kamasaee v Commonwealth’ (2018) 19:1 Melbourne Journal of International Law 52.

146 Christina Fink, 'Dangerous Speech, Anti-Muslim Violence, and Facebook in Myanmar' (2018) 71:1.5 Journal of International Affairs 43.

147 Jane Mayer, Dark Money: The Hidden History of the Billionaires Behind the Rise of the Radical Right (New York: Anchor Books, 2017).
} 
intra-corporate level, corporations can determine how they address rights; from this they have the power to determine their own rights priorities and exclusions, in turn affecting global rights discourse; and that corporations are increasingly seeking to influence human rights institutions.

First, corporations have the power to decide, or at least influence, how they choose to address human rights. Here, they translate human rights responsibilities into managerial practices. 'Human rights are articulated as a matter of risk, within "familiar frames" of business discourse, drawing them into operational technologies of measurement and management.' ${ }^{148}$ Human rights become managerial targets rather than ideals. These internalized discourses ensure that rights 'can never fulfil any radical potential we may think they contain'. ${ }^{149}$ For Scheper, business engagement with human rights performs a disciplinary function towards their critics, ${ }^{150}$ as businesses welcome engagement over human rights issues and partnerships with non-governmental organizations (NGOs) and others, ${ }^{151}$ while concurrently educating these organizations as to the distinct pressures businesses face in meeting human rights responsibilities. ${ }^{152}$ Thus, business practicalities shape the form and extent of intra-corporate human rights practice. ${ }^{153}$ This approach has the benefit of producing more immediate, tangible gains than its opposite, but only by reneging on any promise that rights could lead to the fulfilment of human development.

Second, the managerialism of human rights produces certain priorities and exclusions. Priorities include those civil and political rights issues that are largely uncontroversial in their major markets. Exclusions cover those areas that affect profit, not least their own labour rights issues. Companies use human rights to reconstruct their image along 'social purpose' lines. ${ }^{154}$ Wettstein and Baur identify examples of corporations speaking out in favour of refugees, marriage equality and anti-racism. ${ }^{155}$ Here corporations are behaving as political activists. However, they are activists with specific priorities, which rarely or never take controversial stances in major markets. Nike has made advertisements challenging racial discrimination in the US, ${ }^{156}$ and has pulled products from sale in mainland China because the designer voiced support for greater autonomy in Hong

\footnotetext{
148 Ciarán O’Kelly, 'Human Rights and the Grammar of Corporate Social Responsibility' (2019) 28:5 Social \& Legal Studies 625, 642.

149 Ibid, 18.

150 Christian Scheper, "From Naming and Shaming to Knowing and Showing": Human Rights and the Power of Corporate Practice' (2015) 19:6 The International Journal of Human Rights 737, 738.

151 See on the complexity of business-NGO partnerships and their potential corruption: Fiona McGaughey, 'From Gatekeepers to GONGOs: A Taxonomy of Non-Governmental Organisations Engaging with United Nations Human Rights Mechanisms' (2018) 36:2 Netherlands Quarterly of Human Rights 111.

152 Scheper, note $150,745-7$.

153 Ibid, 743-4, 751.

154 Seth Green, 'Going Beyond Ethics and Compliance: The Growing Corporate Movement to Embrace Social Value Creation’ (2017) 49 Loyola University of Chicago Law Journal 573.

155 Florian Wettstein and Dorothea Baur, “Why Should We Care about Marriage Equality?": Political Advocacy as a Part of Corporate Responsibility’ (2016) 138:2 Journal of Business Ethics 208.

156 'Nike Releases Full Ad Featuring Colin Kaepernick - Video', The Guardian (17 September 2018), https:// www.theguardian.com/sport/video/2018/sep/07/nike-releases-full-ad-featuring-colin-kaepernick-video (accessed 24 September 2020).
} 
Kong. ${ }^{157}$ While racial discrimination is hardly a settled subject in the US, these examples suggest that a strategic choice was made that the former would be good for business in aggregate, and the latter would not. Barclay's sponsorship of London Pride can be contrasted with its promotion of large-scale tax avoidance in some of the poorest subSaharan African states. ${ }^{158}$ This suggests a strong, and logical, preference for those progressive causes that assist, or at least do not threaten, their core business, and a disregard for the harm their own profit-seeking causes. It hardly needs explicating that these companies could far more effectively address their own socio-economic impacts than they can address enculturated discrimination. Progressive agendas can be conceived as an attempt to build political capital that can be used to stultify critique over other issues more directly connected to profits. Human rights responsibilities are proving acceptable insofar as they do not hurt the share price.

Finally, businesses are increasingly impacting the field of BHR itself. As Deva frames it, there is a developing shift from business and human rights, to the business of human rights. ${ }^{159}$ This encompasses the managerial practices above, but also the mushrooming BHR consultancy business, where a symbiosis between corporations and consultants develops around issues of practice such as human rights due diligence. The consultants want clients and are incentivized to construct responsibilities in an achievable way. Businesses gain the kudos of having a legitimate outside agent manage their human rights issues. ${ }^{160}$ This manifests at the UN Forum on Business and Human Rights, where both companies and consultants dominate proceedings, while critical voices are marginalized. Van Ho notes that at the 2019 Forum just 4.2 per cent of speakers were from academia, ${ }^{161}$ and that 'Nestlé [was granted] a forum for self-promotion on their work in the cocoa industry' despite causing ongoing harm therein. ${ }^{162}$ A related issue is the growing corporate influence at the UN, wherein corporations are seen as essential development partners, particularly spurred by the Global Compact and efforts to meet the Sustainable Development Goals. ${ }^{163}$ Again, their voice is elevated, legitimized, and therefore made more powerful. While some managers may desire to help, and win-win cases do exist, these companies remain profit-driven and will not be answering questions of rights and development from a purely rights-based perspective. Powerful corporate voices at these important institutions create a serious risk that BHR will evolve to further exclude economic questions and that risk to profit will continue to be the true red line of engagement.

\footnotetext{
157 Tom Hancock, 'Nike Pulls Line of Shoes From China Over Instagram Post', Financial Times (26 June 2019), https://www.ft.com/content/8e034184-972b-11e9-8cfb-30c211dcd229 (accessed 24 September 2020).

158 Mosselmans, note 111.

159 Surya Deva, 'From "Business or Human Rights" to "Business and Human Rights": What Next?' in Surya Deva and David Birchall (eds.), Research Handbook on Human Rights and Business (Cheltenham: Edward Elgar, 2020), 5.

160 Ibid, 6.

161 Tara Van Ho, 'Academics at the Forum: Yes it Still Matters, No It's Not Any Better - Part 1', Business and Human Rights Journal Blog (21 November 2019), https://www.cambridge.org/core/blog/2019/11/21/academics-at-the-forumyes-it-still-matters-no-its-not-any-better-part-1/ (accessed 24 September 2020).

162 Tara Van Ho, 'Academics at the Forum: Yes it Still Matters, No It's Not Any Better - Part 2', Business and Human Rights Journal Blog (22 November 2020), https://www.cambridge.org/core/blog/2019/11/22/academics-at-the-forumyes-it-still-matters-no-its-not-any-better-part-2/ (accessed 24 September 2020).

163 Deva, note 159, 6-7, 9.
} 


\section{Conclusion}

This article has addressed the issue of corporate power over human rights. Using theories of power developed primarily within international relations literature, it has argued that corporations hold power within four distinct sites relevant to human rights: power over individuals; power over materialities; power over institutions; and power over knowledge. This disaggregation contributes towards evolving understandings of the extent of business impacts upon human rights and provides a framework through which researchers can consider this broader range of impacts. It encourages researchers to dig down into the political economy of corporate activity and its effects on human rights, and to note the various means by which rights possibilities may be stifled a priori to current modes of legal enforcement or proactive corporate responsibility policy. It serves a further function in providing linkages between disparate forms of corporate activity. A corporation that may be discursively supportive of human rights and with no ongoing legal cases may still be working against human rights in another area, and this framework allows these contrasts to be highlighted.

More immediately the framework can contribute to debates around the scope of the UNGPs, emerging human rights due diligence legislation, and the planned business and human rights binding treaty. ${ }^{164}$ Many of the forms and outcomes of corporate power cited above are currently beyond the scope of BHR regulation, and as soft regulation becomes hard legislation there is a trend towards more minimal standards. The French Duty of Vigilance law, for example, is restricted to 'the prevention of severe violations of human rights and fundamental freedoms, serious bodily injury or environmental damage or health risks'. ${ }^{165}$ This reduces the scope of human rights due diligence either for reasons of political palatability and/or legal enforceability. Other documents suffer from an indeterminacy problem. ${ }^{166}$ The current (2nd revision) of the binding treaty offers that 'State Parties shall ensure that their domestic law provides for [the legal liability of business actors for human rights abuses]'. ${ }^{167}$ Human rights abuse is defined as:

any harm committed by a business enterprise, through acts or omissions in the context of business activities, against any person or group of persons, that impedes the full enjoyment of internationally recognized human rights and fundamental freedoms, including regarding environmental rights. ${ }^{168}$

\footnotetext{
164 Nicolas Bueno and Claire Bright, 'Implementing Human Rights Due Diligence Through Corporate Civil Liability' (2020) International \& Comparative Law Quarterly 69.4 (2020): 789-818; Jonathan Kolieb, 'Advancing the Business and Human Rights Treaty Project through International Criminal Law: Assessing the Options for Legally-Binding Corporate Human Rights Obligations' (2018) 50 Georgetown Journal of International Law 789.

165 European Coalition of Corporate Justice, 'French Corporate Duty of Vigilance Law (English Translation', Respect International (2016), http://www.respect.international/french-corporate-duty-of-vigilance-law-english-translation/ (accessed 24 September 2020).

166 David Birchall, 'Between Apology and Utopia: The Indeterminacies of the Zero Draft Treaty on Business and Human Rights' (2020) 49:3 Suffolk Transnational Law Review (forthcoming).

167 Open-Ended Intergovernmental Working Group Chairmanship, Second Revised Draft: Legally Binding Instrument to Regulate, in International Human Rights Law, the Activities of Transnational Corporations and Other Business Enterprises, 6 August 2020, Art 8.1, https://www.ohchr.org/Documents/HRBodies/HRCouncil/WGTransCorp/ Session6/OEIGWG_Chair-Rapporteur_second_revised_draft_LBI_on_TNCs_and_OBEs_with_respect_to_Human_ Rights.pdf (accessed 24 September 2020).

168 Ibid, article 1.2 of the draft treaty.
} 
This ostensibly covers any act or omission that 'impedes the full enjoyment' of human rights. Acts such as transferring a worker to a zero-hour contract, photographing remote workers, and those which contribute to climate change would appear to impede, more or less directly, the full enjoyment of individuals' human rights. Indeed, the phrasing 'impede full enjoyment' seems deliberately inclusive, overtly going beyond human rights violations that may also constitute domestic crimes or civil wrongs. A further example cited above, transfer mispricing, tests the limits here. Transfer mispricing impedes full enjoyment of human rights for millions of people by significantly reducing the ability of some of the world's poorest states to protect rights. But do the treaty drafters seek to include transfer mispricing as a human rights abuse? No positive statement has been made explicating that it is covered, and so it may be assumed to be outside the scope. If so, according to the treaty, transfer mispricing does not impede enjoyment of human rights. ${ }^{169}$ Although left unclarified in the draft treaty, there is probably a de facto/de jure distinction to made, that while certain acts may in practice impede enjoyment of human rights, only those that constitute legal breaches of individuals' rights will be covered therein and the extraterritorial application of these norms will be the big gain. ${ }^{170}$ As tax avoidance does not directly impede any specific individuals' rights it will not constitute an impediment to the full enjoyment of human rights under the treaty, despite its deleterious macro-level impact. The same will likely apply to business activities permitted under domestic law, such as increasing precarious work. ${ }^{171}$

This mitigates the risk of over-ambition discouraging ratification but does so only by furthering the problem of legalism within BHR. The four forms of corporate power and their myriad specific variants are used to profit from impeding the full enjoyment of human rights beyond legally recognized forms of harm. While respecting the need for clear legal standards, BHR advocates must foreground the awareness that corporations are powerful actors whose influence extends through every aspect of life. If BHR seeks to ensure that corporations respect human rights, both the understandings of human rights and of 'business activity' must be broad enough to ensure that corporations are respecting human rights meaningfully. Otherwise, BHR risks conforming to the critical view of human rights as a veneer for further asserting (neo)liberalism globally, ${ }^{172}$ that is disinterested in economic justice. ${ }^{173}$ Given that BHR targets economic actors, economic rights issues must be pivotal to the movement. A set of regulations that ignore material and institutional

\footnotetext{
169 The Center for Economic and Social Rights (CESR) has done extensive work on tax justice and human rights. For an overview, see CESR, 'Tax Justice and Human Rights: An Overview of Materials', https://www.cesr.org/sites/default/ files/CESR\%20-\%20Tax\%20justice\%202\%20pager\%202020.pdf (accessed 24 September 2020).

170 Tori Loven Kirkebø and Malcolm Langford, 'Ground-Breaking? An Empirical Assessment of the Draft Business and Human Rights Treaty’ (2020) 114 AJIL UNBOUND 179, 184.

171 The Committee on Economic, Social and Cultural Rights state that precarious work should be 'gradually eliminated', suggesting that it believes precarity to 'impede the full enjoyment' of the right to just work. See CESCR, note 143 , para 21 .

172 Stephen Hopgood, The Endtimes of Human Rights (Ithaca, NY: Cornell University Press, 2013); Jessica Whyte, The Morals of the Market: Human Rights and the Rise of Neoliberalism (New York: Verso Books, 2019), 19 and throughout.

173 Samuel Moyn, Not Enough: Human Rights in an Unequal World (Cambridge, MA: Harvard University Press, 2018), particularly chapter 7 .
} 
power, ignore the role of corporations in determining access to resources and in shaping preferences, is inadequate. Extant legal structures have failed to create ethical corporations, and universalizing access to these structures is necessary but insufficient.

Finally, this paper has focused on providing examples that are intrinsic to contemporary business practice, serious, and easily understood, while also balancing some mainstream BHR issues with those largely beyond the current scope. Inevitably, many rights-issues have not been covered, such as racial and gender discrimination, children's rights, cultural rights and conflict. Corporations have a role in shaping child development, for example, through advertising, products, media and online entertainment, and their actions therein may cause harm to children's rights. One of the most important uses of this framework would be to turn it to such specific cases to understand the impacts therein. Equally useful would be to focus on a specific company to understand its operations within the four sites. Such projects should provide a basis for the development of a more comprehensive form of BHR, in which corporations are encouraged to respect all human rights through all exercises of their power in the global economy. 